\title{
UNIVERSITY OF GRANADA RADIOCARBON DATES VIII
}

\section{CECILIO GONZÁLEZ-GÓMEZ}

Consejo Superior de Investigaciones Científicas (CSIC) and Departamento de Química Inorgánica, Laboratorio de Radioquímica y Radiología Ambiental, Facultad de Ciencias, Universidad de Granada, E-18071 Granada, Spain

and

\section{ELENA VILLAFRANCA-SÁNCHEZ}

Centro de Instrumentación Científica, Servicios Técnicos de Apoyo a la Investigación, Universidad de Granada, E-18071 Granada, Spain

\section{INTRODUCTION}

This paper includes determinations of archaeological, geological and paleobotanical samples from Spain and Brazil, measured at the University of Granada Radiocarbon Dating Laboratory, mainly from 1991 to 1992. As previously reported (González-Gómez 1992), pretreatment of charcoal and wood samples is a standard acid-basic procedure using $8 \% \mathrm{HCl}$ and $2 \% \mathrm{NaOH}$ at boiling temperature. The collagen of bone samples was extracted by the Longin (1971) method. The method of dating is liquid scintillation counting of synthesized benzene.

The sample size and the scintillator was $7 \mathrm{~mL}$ low ${ }^{40} \mathrm{~K}$ Packard counting picovials with $5 \mathrm{~mL}$ synthesized benzene and $83.5 \mathrm{mg}$ Butyl-PBD directly dissolved in the benzene $\left(16.7 \mathrm{~g} \mathrm{~L}^{-1}\right)$ as a scintillator; smaller samples were expanded to $5 \mathrm{~mL}$ with inactive benzene. ${ }^{14} \mathrm{C}$ activity was measured in a Packard Tri-Carb ${ }^{\circledR}$ Mod 4640 liquid scintillation spectrometer. Efficiency was $\sim 65 \%$ using the part of the spectrum above the endpoint of tritium, with a background of $\sim 7 \mathrm{cpm}$. At least one modern reference standard and two background vials were measured together with each series of measurements. All results are corrected for fractionation according to the quoted $\delta^{13} \mathrm{C}$ (w.r.t. PDB) values.

In order to prevent any loss of benzene during counting and storage, we sealed the vials hermetically with a metallic cap. The joint was made of a $3 \mathrm{~mm}$ silicone $+0.05 \mathrm{~mm}$ Teflon ${ }^{\circledR}$ sheet. As a second barrier we placed a silicone O-ring, $10 \mathrm{~mm}$ in inner diameter and $2 \mathrm{~mm}$ thick, around the neck of the vial. The weight of vials, checked one year after filling, remained unchanged (González-Gómez 1992).

Dates reported here are based on 0.95 of the activity of NBS HOxI, on the Libby ${ }^{14} \mathrm{C}$ half-life of $5568 \mathrm{yr}$, and expressed in radiocarbon years relative to $\mathrm{AD} 1950$, as suggested by Stuiver and Polach (1977). Samples, backgrounds and standards were measured for 40-45 100-min intervals. The standard deviation quoted includes only $1 \sigma$ of the counting statistics of background, sample and modern standard counts. Calculations and data were processed using a PC running a general program for radiocarbon dating laboratories written by González-Gómez (1995). Calibrated ages for a $2 \sigma$ interval were obtained by the method of Pearson et al. (1986) running the computer programs CALIB (Stuiver and Reimer 1993) and CALI (González-Gómez 1988) and using the bidecadal curve for samples of atmospheric origin. Sample descriptions and comments are essentially based on information provided by submitters. 


\section{ACKNOWLEDGMENT}

We thank the Departamento de Química Analítica, Facultad de Química, Universidad de Barcelona, for the $\delta^{13} \mathrm{C}$ determinations.

\section{ARCHAEOLOGICAL SAMPLES}

SPAIN

\section{Alcazaba de Loja Series}

Charcoal samples from Alcazaba de Loja $\left(37^{\circ} 09^{\prime} \mathrm{N}, 4^{\circ} 29^{\prime} \mathrm{W}\right)$, Loja, Granada province, were collected and submitted from 1991 to 1993 by J. A. Alonso-Martínez, Loja Council.

UGRA-402. H.CH.(A-91)C-14

$$
\begin{array}{r}
2610 \pm 70 \\
\delta^{13} C=-25.7 \% \circ
\end{array}
$$

Comment: Sample from depth $4.5 \mathrm{~m}$; to date the most recent archaeological levels of the site establishment in the Loja Alcazaba (castle); 910-540 cal BC.

UGRA-464. LOJA 93

$$
\begin{array}{r}
3900 \pm 60 \\
\delta^{13} C=-23.9 \%
\end{array}
$$

Comment: Sample from depth $4.5 \mathrm{~m}$; to date archaeological levels at the base of the Loja Alcazaba hill; 2573-2200 cal BC.

\section{University of Salamanca Lecture-Room Series}

Wood samples from an historic lecture-room at the University of Salamanca were collected and submitted 1991 to date the age of a lecture-room used by Fray Luis de León for his lectures in that University.

UGRA-388. $\mathrm{n}^{2} 1$

$$
\begin{array}{r}
\mathbf{5 3 0} \pm \mathbf{4 5} \\
\delta^{13} C=-24.4 \%
\end{array}
$$

Sample from a plank of the floor under the second seat on the right side; cal AD 1304-1443.

UGRA-390. $n^{2} 2$

Sample from the fourth seat on the right side; cal AD 1464-1656.

$315 \pm 40$

UGRA-391. $\mathrm{n}^{2} 3$

$\delta^{13} C=-23.2 \%$

Sample from the floor-boarding under the professor's seat; cal AD 1410-1630. $\delta^{13} C=-21.9 \%$

UGRA-410 Cueva de los Olivos. HUESCAR 1

$1490 \pm 40$

$\delta^{13} C=-19.2 \%$

Bones from Cueva de los Olivos $\left(37^{\circ} 46^{\prime} \mathrm{N}, 2^{\circ} 31^{\prime} \mathrm{W}\right)$, Huescar, Granada province. Sample collected and submitted 1991 by J. Aguilera, Granada, to date a grave and the time of the zone's occupation. Sample from depth $40 \mathrm{~cm}$; cal AD 444-645.

\section{San Miguel de Lillo Series}

Wood samples from the church San Miguel de Lillo $\left(43^{\circ} 23^{\prime} \mathrm{N}, 5^{\circ} 52^{\prime} \mathrm{W}\right)$, Oviedo, Asturias province, were collected and submitted 1991 by C. García de Castro, Facultad de Geografía e Historia, Universidad de Oviedo.

UGRA-417. LILLO 1

$1090 \pm 80$

cal AD 770-1113.

$\delta^{13} C=-25.0 \%$ 
UGRA-418. LILLO 2

$880 \pm 45$

cal AD 1027-1253.

$\delta^{13} \mathrm{C}=-25.0 \%$

Comment: These two samples from a height of $6.0 \mathrm{~m}$ above the ground were to date the widely debated date of erection of the church apse.

UGRA-419. LILLO 3

$245 \pm 40$

cal AD 1521-1954.

$\delta^{13} C=-24.0 \%$

Comment: Sample from a height of $10.9 \mathrm{~m}$ to date the repair of the building cornice and other nondated works.

UGRA-396. Santa Ana 4 y 6. PRIEGO.

$685 \pm 40$

$\delta^{13} C=-25.6 \%$

Wood sample from Santa Ana 4 y $6\left(37^{\circ} 26^{\prime} \mathrm{N}, 4^{\circ} 11^{\prime} \mathrm{W}\right)$, Priego de Córdoba, Córdoba province, collected and submitted 1991 by R. Carmona, to date the walled precinct in the town; cal AD 12631387.

\section{GeOLOGICAL SAMPLES}

SPAIN

UGRA-394. Fines. ZL-5002.

$280 \pm 40$

$\delta^{13} \mathrm{C}=-24.9 \%$

Charcoal sample from Fines $\left(37^{\circ} 23^{\prime} \mathrm{N}, 2^{\circ} 11^{\prime} \mathrm{W}\right)$, Almería province, collected and submitted 1991 by L. García-Rossell, Instituto Andaluz de Ciencias de la Tierra (IACT), Consejo Superior de Investigaciones Científicas (CSIC), Facultad de Ciencias, Universidad de Granada, to date the industry associated with a furnace excavated in the marls. Sample from depth $3 \mathrm{~m}$; cal AD 1486-1666.

\section{Travertinos de Nívar Series}

Travertine samples from Nívar $\left(37^{\circ} 16^{\prime} \mathrm{N}, 3^{\circ} 34^{\prime} \mathrm{W}\right)$, Granada province, collected by M. Martín-Martín and submitted 1991 by A. Martín-Algarra, Departamento de Estratigrafía y Paleontología, Facultad de Ciencias, Universidad de Granada, to date Quaternary formations in the Granada basin, and to study the morphostratigraphy and recent climatic evolution of the zone. Samples were taken from the ground.

UGRA-399. NIVAR-1

$13,210 \pm 110$

UGRA-400. NIVAR-4

$\delta^{13} C=-6.9 \%$

UGRA-401. NIVAR-8

$20,900 \pm 200$

$\delta^{13} \mathrm{C}=-7.8 \%$

UGRA-404. NIVAR-10

$32,600 \pm 900$

$\delta^{13} C=-6.3 \%$

UGRA-405. NIVAR-11

$35,500 \pm 1300$

$\delta^{13} \mathrm{C}=-8.1 \%$

$>45,000$

UGRA-406. NIVAR-12

$\delta^{13} \mathrm{C}=-7.6 \%$

$37,200 \pm 1500$

$\delta^{13} \mathrm{C}=-7.5 \%$

UGRA-407. NIVAR-13

$36,200 \pm 1600$

$\delta^{13} \mathrm{C}=-8.0 \%$ 
BRAZIL

\section{UGRA-395 Playa de Foguete FOGUETE}

$3930 \pm 50$

$\delta^{13} C=-19.9 \%$

Peat from Playa de Foguete $\left(23^{\circ} 05^{\prime} \mathrm{S}, 42^{\circ} 02^{\prime} \mathrm{W}\right)$, Arraial do Cabo, Rio de Janeiro, Brazil. Sample collected 1991 by A. Cendrero-Uceda and submitted 1991 by L. Salas-Gómez, CDITTYM, División de Ciencias de la Tierra, Universidad de Cantabria, Santander, to date the age of the Flandrian transgression in the coast of Rio de Janeiro State, Brazil. Sample from the ground; expected age was $\sim 5460 \pm 1500$ BP; $2577-2300$ cal BC.

\section{Paleobotanical SAMPles}

SPAIN

UGRA-377. Pico del Lobo. PLB II C"

$1170 \pm 80$

$\delta^{13} C=-28.2 \%$

Peat from Pico del Lobo $\left(40^{\circ} 59^{\prime} \mathrm{N}, 3^{\circ} 58^{\prime} \mathrm{W}\right)$, La Pinilla, Segovia province; sample was collected and submitted 1989 by M. J. Gil-García, Departamento de Geología, Universidad de Alcalá de Henares, Madrid province, to establish the botanical history of that zone; cal AD 670-1020.

\section{UGRA-380. Hayedo de Montejo. HM I (50-55)}

$>$ Modern

$\delta^{13} C=-27.9 \%$

Peat from Hayedo de Montejo ( $41^{\circ} 05^{\prime} \mathrm{N}, 3^{\circ} 30^{\prime} \mathrm{W}$ ), Montejo de la Sierra, Madrid province; sample was collected and submitted 1990 by M. J. Gil-García, Departamento de Geología, Universidad de Alcalá de Henares, Madrid province, to establish the vegetation history of the zone.

\section{Laguna del Hornillo Series}

Peat samples from Laguna del Hornillo $\left(41^{\circ} 57^{\prime} \mathrm{N}, 2^{\circ} 51^{\prime} \mathrm{W}\right)$, Covaleda, Soria province, were collected and submitted from 1991 to 1992 by A. Gómez-Lobo, Departamento de Geología, Universidad de Alcalá de Henares, Madrid province, to establish the botanical history of the zone. To date the situation of different stages of Holocene vegetation.

UGRA-416. VLH-270

Sample from depth $2.7 \mathrm{~m}$; 6080-5429 cal BC.

UGRA-440. VLH-110

Sample from depth $1.1 \mathrm{~m}$; 3932-3379 cal BC.

UGRA-441. VLH-200

Sample from depth $2.0 \mathrm{~m}$; 5311-4853 cal BC.

$$
\begin{array}{r}
6860 \pm 170 \\
\delta^{13} C=-29.0 \% 0 \\
4860 \pm 90 \\
\delta^{13} C=-29.0 \% 0 \\
6150 \pm 90 \\
\delta^{13} C=-29.0 \% 0 \\
1080 \pm 60 \\
\delta^{13} C=-28.1 \% 0
\end{array}
$$

Peat from Nevero ( $41^{\circ} 00^{\prime} \mathrm{N}, 3^{\circ} 50^{\prime} \mathrm{W}$ ), Sierra de Guadarrama, Pinilla del Valle, Madrid province, collected 1988 by R. Vázquez-Gómez and submitted 1990 by M. Peinado-Lorca, Departamento de Biología Vegetal, Botánica, Universidad de Alcalá de Henares, Madrid province, to establish the date of expansion of Juniperus brushwood and the disappearance of a pine wood existing in that zone. Sample from 50-70 cm; cal AD 809-1030.

\section{Peñalara Series}

Peat samples from Peñalara $\left(40^{\circ} 50^{\prime} \mathrm{N}, 4^{\circ} 00^{\prime} \mathrm{W}\right)$, Sierra de Guadarrama, Rascafría, Madrid province, collected 1989 by R. Vázquez-Gómez and submitted 1990 by M. Peinado-Lorca, Departamento de Biología Vegetal, Botánica, Universidad de Alcalá de Henares, Madrid province. 
UGRA-378. PÑB (20-30)

$2800 \pm 50$

Sample from depth $20-30 \mathrm{~cm} ; 1090-840 \mathrm{cal} \mathrm{BC}$.

$\delta^{13} C=-27.7 \%$

UGRA-381. PÑB (80-90)

$1100 \pm 60$

Sample from depth 80-90 cm; cal AD 780-1020.

$\delta^{13} C=-28.1 \% 0$

UGRA-382. PÑB (150-160)

$4160 \pm 70$

Sample from depth 1.5-1.6 m; 2920-2505 cal BC.

$\delta^{13} C=-27.1 \%$

Comment: The former samples were to date the possible felling of Pinus sylvestris.

UGRA-384. PHV

Sample from depth 74-85 cm; 354 cal BC-cal AD 80 .

$2060 \pm 70$

UGRA-385. PHIA

$\delta^{13} C=-28.0 \%$

Sample from depth 58-68 cm; 1890-1440 cal BC.

$3350 \pm 90$

$\delta^{13} \mathrm{C}=-28.3 \%$

Comment: These samples were to establish if the expansion of Pinus sylvestris coincided with the disappearance of a Betula wood existing in the vicinity of the peat bog.

\section{REFERENCES}

González-Gómez, C. 1988 CALI, a computer program for calibration of radiocarbon dates. Unpublished software.

1992 University of Granada radiocarbon dates VI. Radiocarbon 34(1): 133-139.

1995 A general computer program for radiocarbon dating laboratories. In Cook, G. T., Harkness, D. D., Miller, B. F. and Scott, E. M., eds., Proceedings of the 15th International ${ }^{14} \mathrm{C}$ Conference. Radiocarbon 37 (2): 789-790.

Longin, R. 1971 New method of collagen extraction for radiocarbon dating. Nature 230: 241-242.
Pearson, G. W., Pilcher, J. R, Baillie, M. G. L., Corbet, D. M. and Qua, F. 1986 High-precision ${ }^{14} \mathrm{C}$ measurements of Irish oaks to show the natural ${ }^{14} \mathrm{C}$ variations from AD 1840 to 5210 BC. In Stuiver, M. and Kra, R., eds., Calibration Issue. Radiocarbon 28(2B): 911934.

Stuiver, M. and Polach, H. 1977 Reporting of ${ }^{14} \mathrm{C}$ data. Radiocarbon 19(3): 355-363.

Stuiver, M. and Reimer, P. J. 1993 Extended ${ }^{14} \mathrm{C}$ data base and revised CALIB $3.0{ }^{14} \mathrm{C}$ age calibration program. In Stuiver, M., Long, A. and Kra, R. S., eds., Calibration 1993. Radiocarbon 35(1): 215-230. 